\title{
Article
}

\section{An investigation into agile learning processes and knowledge sharing practices to prevent identity theft in the online retail organisations}

Shah, Mahmood Hussain, Maitlo, Abdullah, Jones, Paul and Yusuf, Yahaya

Available at http://clok.uclan.ac.uk/25974/

Shah, Mahmood Hussain, Maitlo, Abdullah, Jones, Paul and Yusuf, Yahaya ORCID: 0000-0001-6045-3245 (2019) An investigation into agile learning processes and knowledge sharing practices to prevent identity theft in the online retail organisations. Journal of Knowledge Management . ISSN 13673270

It is advisable to refer to the publisher's version if you intend to cite from the work. http://dx.doi.org/10.1108/JM-06-2018-0370

For more information about UCLan's research in this area go to http://www.uclan.ac.uk/researchgroups/ and search for < name of research Group>.

For information about Research generally at UCLan please go to http://www.uclan.ac.uk/research/

All outputs in CLoK are protected by Intellectual Property Rights law, including Copyright law. Copyright, IPR and Moral Rights for the works on this site are retained by the individual authors and/or other copyright owners. Terms and conditions for use of this material are defined in the policies page. 


\section{eEmerald Journal of}

An investigation into agile learning processes and knowledge sharing practices to prevent identity theft in the online retail organisations

\begin{tabular}{|r|l|}
\hline Journal: & Journal of Knowledge Management \\
\hline Manuscript ID & JKM-06-2018-0370.R2 \\
\hline Manuscript Type: & Research Paper \\
\hline Keywords: & Knowledge sharing, Identity theft, Information security, Case Studies \\
\hline &
\end{tabular}




\title{
An investigation into agile learning processes and knowledge sharing practices to prevent identity theft in the online retail organisations
}

\author{
Abstract \\ Purpose
}

Lack of individual awareness of knowledge sharing practices to prevent identity theft is a significant issue for online retail organisations (OROs). Agile learning processes and sharing of knowledge is essential, but the lack of relevant training inhibits these processes within the online industry. This study identifies the inhibiting factors in the agile learning and knowledge sharing process with recommendations for best practice for organisations and staff to effectively share knowledge on identity theft prevention.

\section{Design/methodology/approach}

Three qualitative case studies were undertaken in OROs in the United Kingdom. Data was collected using semi-structured interviews, internal documents and related external material. The data were analysed using a thematic analysis method.

\section{Findings}

The findings identified that individual staff members within OROs from the information security and fraud prevention departments often share their knowledge as a community. However, there is no formal knowledge sharing process or any related training facilitating this exchange. There is a need for agile learning environment in OROs of the United Kingdom.

\section{Originality/value}

The study offers both theoretical and practical contributions to the extant literature of agile learning of knowledge sharing to prevent identity theft in OROs. Existing learning opportunities are not being used to enhance the knowledge of individuals, and OROs need to increase the skills and trust of their staff to share knowledge efficiently. This study identifies the systemic weaknesses inherent in the process of knowledge sharing and existing training provision within OROs. It provides ORO managers with practical guidelines in facilitating trust between individuals and developing appropriate training systems to educate staff on sharing organisational knowledge. This study contributes by extending the knowledge sharing framework proposed by Chong et al. (2011), for enhanced individual knowledge sharing processes to prevent identity theft within OROs. It also identifies OROs weaknesses in knowledge sharing learning processes for theft prevention and offers prevention guidelines and recommendations for developing effective agile learning environments.

Type Research Paper

Keywords Knowledge sharing, Identity theft, Information security, Staff awareness, Case study, Agile learning. 


\section{Introduction}

Identity (ID) theft refers to fraud carried out by using the identity of any other person, which has become a recurring and topical problem in the business and banking sectors through fraudulent online transactions and retail purchasing (Fennelly, 2004). Currently, ID theft related problems are increasing (Abdullah et al. 2016), and it has become one of the fastestgrowing globally reported crimes (Grover et al., 2011). For example, in the United States of America (USA), millions of people annually are victimised by ID fraudsters, and approximately 20 billion United States Dollars (USD) is allocated to fight theft crimes (Eisenstein, 2008; Abdullah et al., 2016). However, to combat ID theft, consumers spend more than one billion USD, and industries commit over 100 million working hours to alleviate ID fraud (Eisenstein, 2008). Similarly, the United Kingdom (UK) National Fraud Database (NFD) of the Credit Industry Fraud Avoidance Systems (CIFAS) identified 324,683 frauds in 2016 representing a $1.2 \%$ growth on the previous year.

Various organisations and government institutions, such as CIFAS and the UK police have implemented different policies and standards to combat ID fraud (CIFAS, 2017) although this has not had any significant impact upon the increase in reported crimes (Aimeur and Schonfeld, 2011). Aimeur and Schonfeld (2011) claimed that employees typically do not adopt such policies, or even read the policy and security-related guidelines due to the explicit nature of knowledge sharing (KS). This significant organisation problem can be resolved by the appropriate use of knowledge management (KM) (Conrad et al., 2013), whereby staff are required to share knowledge of ID theft prevention effectively.

Online Retail Organisations (OROs) must identify any weaknesses of individual learning processes of ID theft prevention KS to prevent ID theft and provide appropriate solutions for an effective learning environment. ORO are defined here as organisations undertaking electronic commerce whereby consumers buy goods/services directly from a seller through the Internet using a web browser (Eroglu et al., 2001). Thus, the aim of this study is to investigate individual staff KS processes within OROs, providing the solution for an effective learning environment of KM to reduce ID theft. Thus, the objectives of this study are to analyse how individual staff members acquire effective KS techniques to prevent ID theft and identify weaknesses in existing individual learning environments in OROs. Through this investigation, this study offers an effective solution for an enhanced learning environment and a process of $\mathrm{KS}$ to prevent ID theft.

By achieving the research objectives in this study, it provides both theoretical and practical contributions. First, it bridges a gap in the existing literature by identifying the weaknesses of ORO staff learning processes for ID theft prevention and knowledge sharing. Second, it extends a KS framework proposed by Chong et al. (2011) in the new context of ID theft prevention. Third, by providing a new framework by making amendments in the guiding framework for effective individual KS to prevent ID theft in ORO. Fourth, this study offers several practical implications. KS learned, and knowledge about the practice of preventing identity theft can assist staff and organisations to reconsider their processes and evaluate whether their KS procedures are addressing the concerns raised for ID theft prevention in the ORO. Indeed, this research contributes to providing practical guidelines for overcoming the weaknesses of OROs to share individual KS for ID theft prevention.

\section{Background}


Current studies highlight the importance of knowledge in organisations (Zhu et al., 2018; Wiredu, 2012). Most organisations are typically considered knowledge-oriented having an agile learning environment (Annosi et al., 2018), which focus on developing and providing such services to staff (Luen and Al-Hawamdeh, 2001; Huang, 2014; Henttonen et al., 2016). Thus, knowledge is considered a leading resource for such organisations (Willem and Buelens, 2007; Singh Sandu et al., 2011; Siong et al., 2011; Wang et al., 2014) and staff are required to enhance the learning processes of KS (Sedighi et al., 2018; Kowta Sita and Chitale, 2012). Therefore, enabling effective agile learning processes (Xiong et al., 2018) and efficient KS processes and improving the management of individual KS are challenging issues in the private sector (Kim and Lee, 2006; Silvi and Cuganesan, 2006). An increasing number of public and private sector organisations are working on agile learning (Gan et al., 2015) and creating KM protocols to provide effective systems and practices for the sharing and use of the knowledge that they generate and manage (Brantingham et al., 2017; Uden and He, 2017).

There is growing appreciation for the active role of staff in KS (Serenko and Bontis, 2016) and agile learning (Noguera et al., 2018), in addition to the increased focus on individual's perspective of knowledge used within organisations (Stenmark, 2000). This perception recognises that employees possess the knowledge (Grant and Baden-Fuller, 2004) although they need to learn about efficient KS practices (Real et al., 2014). Therefore, the significance of agile learning processes (Kropp et al., 2014) and successfully sharing knowledge is currently considered dependent on the connections between individual employees and learning from each other in any organisation (Wenger et al., 2002; Iqbal et al., 2015; Pee and Min, 2017). An agile learning environment is required for effective KS to prevent ID theft within organisations (Abdullah et al. 2016; Dong et al., 2016) and employees are required to learn to be able to share their knowledge (Iqbal et al., 2015).

An agile learning method is beneficial for employees working in an organisation. Combining strategies to assist teams to efficiently standardise group work and improve planning processes can result in increasing workers' engagement with collaborative processes and learning activities. Therefore, the agile learning environment within OROs is effective for increasing the knowledge of organisation employees. Noguera et al. (2018) study found agile strategies are effective in increasing the knowledge of people working in organisations and improves the efficiency of employees and management for collaborative project working (Gandomani et al., 2014; Fontana et al., 2015).

There is growing evidence emphasising the significance of individual employees and their priority in the process of organisational KS (Andrews and Delahaye, 2000). Amongst these processes, useful KS by employees plays a significant role in an organisation's competitive advantage and consistent ongoing performance (Kane et al., 2005; Nonaka and Peltokorpi, 2006; Wang and Hou, 2015). Hence, efficient KS can be an essential production driver in OROs (Gray and Laidlaw, 2002; Silvi and Cuganesan, 2006). In accordance with Chow and Chan (2008), Chang and Chuang (2011) and Chow and Chan (2008) this study accepts that KS activities are encouraged and implemented, especially at an individual level, and employees are required to learn for effective KS to prevent ID theft (Abdullah et al., 2016). The ability of an organisation to efficiently use its knowledge substantially depends on its employees, who create, use and share knowledge for enhanced awareness of ID theft with other organisation employees (Yang, 2007).

A consideration of the aspects about KS regarding individual staff performance levels is nascent in the extant literature in the context of the learning process of ID theft prevention (Lu et al., 2006). Whereas numerous studies consider the drivers of individual staff KS within 
organisations (Chow and Chan, 2008; Tohidinia and Mosakhani, 2010; Chang and Chuang, 2011; Park and Kim, 2018), there is limited evidence advocating understanding the agile learning processes of employees in sharing the knowledge of ID theft prevention in OROs. This omission is highlighted by He and Wei (2009), Lai et al. (2016) and Yildirim (2016) who noted the neglect of the connections regarding individual KS and the learning environment for enhancing understanding of individuals working in OROs.

The extant research has typically focused on sharing knowledge within public sector organisations (Willem and Buelens, 2007; Yao et al., 2007; Singh Sandhu et al., 2011; Titi Amayah, 2013), with few empirical studies in the private sector (Lai et al., 2016; Yildirim, 2016). Thus an investigation of how employees share their knowledge of ID theft prevention in OROs is required (Yildirim, 2016). Employees working in OROs deal with the product, the customers and organisational information. Whereas, the literature states that currently, ID theft is one of the significant issues in the UK and globally (Brantingham et al., 2017; Zaeem et al., 2017). ID fraudsters are adept at using novel methods for stealing personal information (Madiwalar, 2016). It is too easy for them to steal personal and organisational information from employees responsible for such information (Abdullah et al., 2016). Therefore, individual staff members are required to enhance their knowledge of ID theft issues and how to secure data from fraudsters (Yildirim, 2016). Thus, OROs require an investigation into agile learning processes and staff KS to prevent ID theft. To inform this research gap, this study analyses the processes of learning by employees to effectively share the knowledge of ID theft prevention and the active role of the agile learning environment for employees within OROs.

\section{Insert Table 1 here}

Table 1identifies the key literature regarding employees' KS learning and the requirements for ID theft prevention. It highlights that employees KS is one of the most significant elements of an organisation, where individuals play a vital role in enhancing knowledge. Previously, Singh Sandhu et al. (2011), Titi Amayah (2013), Willem and Buelens (2007) and Yao et al. (2007) have explored individual KS in public sector organisations. However, only a limited number consider agile learning and KS processes from the perspective of individuals employed in private sector organisations, such as Abdullah et al. (2016), Lai et al. (2016) and Yildirim, (2016). The ORO industry requires an investigation in the context of the agile learning process of employees' KS to prevent ID theft. This study fills this gap and identifies three research questions:

1. Evaluate how individual staff members learn effective $\mathrm{KS}$ techniques to prevent ID theft in OROs.

2. Identify the weaknesses in individual learning environments within OROs?

3. Evaluate how to enhance the learning environment and the process of KS to prevent ID theft?

\section{Methodology}

The study adopted a qualitative case study approach, which is appropriate when an investigator seeks to obtain a comprehensive understanding of a situation (Merriam, 2001). The need to effectively understand the social and behavioural context of OROs made a qualitative case study approach suitable and relevant, due to its tradition of providing rich contextual data (Levy 
and Powell, 1999) and enabling a detailed examination of the subject material (Jones et al., 2014). In addition, the limited prior knowledge within this context made a qualitative approach relevant (Hill and Tiu Wright, 2001).

According to Yin (2015), the case study design must include five components: the research question, its propositions, its units of analysis, a determination of how the data are linked to the propositions and criteria to interpret the findings. Yin (2015) suggests that case studies are the ideal approach when "how" and "why" questions are raised. Therefore, such an approach is appropriate for this study given that its main purpose is to gain an understanding of factors influencing how effectively individuals share knowledge regarding identity theft, rather than to make generalisations or prove underlying hypotheses.

The study investigated three OROs in the UK. The methodology literature provides conflicting guidance regarding how many case studies should be selected. Here the aim was to select 'information rich' cases in relation to the research aim namely, those worthy of in-depth study (Ghauri and Gronhaug, 2005; Perry, 1998). Cases were selected to ensure variation, allowing the researchers to identify a spectrum of ORO behaviour regarding KS (Jones et al., 2014). The case study approach includes data collection, data analysis, and reporting and presenting the results of the analysis (Yin, 2015). The study used several data-collection methods namely analysis of internal documents from the selected organisations (including memos and survey reports); analysis of the organisations' websites; an investigation of news about the organisations in print and electronic media; and interviews with staffs working in the participant OROs (Yin, 2015). Both internal and external documents from the OROs were analysed. During site visits, 60 short memos and email conversations and 45 internal policy and working procedure documents were collected from the OROs. The set of internal procedure documents included secure communication, network security, computer protection and data encryption. By using the archival analysis method, these documents were examined to understand the organisation's existing KS processes for identity-theft prevention. The analysis focused on any evidence of identity theft, reasons for stealing data from individuals and the organisation, the steps taken to overcome these problems, and existing agile learning and KS policies and processes for prevention. The external documents investigated included several news sources on the organisations published in print and digital media, including the CCR Magazine, CIFAS, CNN, the BBC, the Telegraph, the Guardian, and others. These reports were examined for any evidence of regarding identity theft and its prevention. The sources were also evaluated for any evidence regarding agile learning processes and KS to prevent ID theft within OROs. Furthermore, the websites of the selected organisations were evaluated, focusing on material regarding KS and the prevention of identity theft.

As discussed earlier, the data collection included semi-structured interviews the participants in the OROs were selected according to their extensive working experience and speciality of knowledge of information security, ID fraud prevention and its KS. The three selected companies had established reputations as OROs in the UK. The companies were large, medium and small sized organisations, having multiple branches in different cities in the country. The case organisations and their contexts are next described. The participant companies wished to remain anonymous. Therefore, the organisations are coded as $\mathrm{CX}, \mathrm{CY}$ and $\mathrm{CZ}$ and interview participants as $\mathrm{CX}, \mathrm{CY}$, and $\mathrm{CZ}$ along with participant number followed by letter R.

This study employs a qualitative case study method and focuses on the perspectives conveyed by respondents. For example, how they undertake their job roles, through which the researchers can understand what is going on in a particular process or situation. The unit of analysis is 
associated with the statement of what the case is (Yin, 2015). Here a case may be a process, a person, an organisation or (as in this study) a project of investigation of the KS processes for ID theft prevention in OROs. The boundaries were set in each case study to define target respondents (individual staff members, teams, departments) to include or exclude, and time limit parameters.

This approach is efficient at illuminating issues and arriving at explanations such as an exploration of meaning (Gillham, 2000). Here researchers seek to inspect issues related to the various operations of individual employees (Creswell, 2003). Therefore, the research team conducted interviews with individual employees to determine their concerns regarding systems operations for agile learning environment and ID theft prevention KS. To ensure robust data collection, as discussed earlier, this study investigated internal documents and related external material in print and electronic media of each case study (Jones et al., 2014).

A case study method protocol was developed to ensure consistency between cases (Yin, 2015). This included case design, data collection, data analysis and reporting and presenting results strategies (Yin, 2015). Initially, the researchers conducted a review of relevant literature to assess the knowledge on ID theft prevention KS, the role of individual employees in the process and existing learning protocols. Thereafter, semi-structured interview questions were developed underpinned by a framework of knowledge transfer proposed by Chong et al. (2011). Table 2 displays the research instrument, which was initially pilot tested using semistructured interviews with eight academic staff in a related discipline. This process resulted in minor changes, such as removal of unrelated and duplicate questions; altering the sequence of questions; and amendment of question-wording to improve clarity. This study gathered several sources of data including interviews, internal documents and external materials. Thirty-four semi-structured interviews were conducted with individual employees ranging from top management to support staff in each case. The interview length varied between 45 to 75 minutes. Tables 3, 4 and 5 profiles interview participants. The researchers also examined internal documents from the researched companies to understand the existing roles of individual employees in the process of KS to prevent ID theft and the learning processes of effective KS. This included analysing internal reports, memorandums and emails to identify evidence of ID theft, its causes and employee behaviour to overcome these issues (Bürgin, 2017). The study also investigated external related material to the case studies including media reports and sector industry surveys published in print and digital media (Bürgin, 2017).

\section{Insert Table 2 here}

At the outset of the data collection process, the investigators attained formal agreement with the management of the participant OROs, according to the ethical approval gained from the parent university, to ensure that the research was conducted as per the University Code of Conduct. The research ethics process was an essential protocol as it provided informed consent to participants and also protected their right to privacy. The investigators made initial contacts with the senior management of the case OROs. The OROs approved access by signing an agreement of confidentiality. All participants were selected according to their working experience and knowledge of information security, ID fraud prevention and KS.

Regarding data collection, two of the interviews were conducted by telephone while the remaining were face-to-face interviews. The same data collection instrument was used in both instances (Jones et al., 2014). The procedure of having an alternative method of either a telephonic or face-to-face semi-structured interview allowed the investigators to gain the 
support of the contributors (David, 2004) and offer flexibility in data collection. Documents were collected to investigate the existing methods of ID theft prevention and staff awareness policies for protecting their organisational knowledge, and current procedures for ID theft identification and prevention.

To analyse the data logically, a coding system was employed to categorise the data (Jones et al., 2014). As suggested by Miles and Huberman (1994) this involved a process of data reduction, display and conclusion drawing and verification. Data were sorted into groups relating to research themes identified in the literature (Smith, 1991). These categories were then coded using terms that emerged from the data analysis process (Strauss and Corbin, 1998). The analysis method employed thematic analysis through a qualitative coding process (Braun and Clarke, 2006). The data were analysed using NVivo software and organised by coding examples in which various aspects of ID theft prevention were explored.

\section{Findings}

An overview of each case study is now provided. CX was a leading multi-brand retailer with approximately $£ 2$ billion annual sales, with multiple active customers that received millions of products annually. Over three-quarters of sales were processed online, one-third of these generated from mobile devices. Approximately one million customers visited the website daily. Due to their privacy request, this study did not include further details of CX. Table 3 describes the list of participants highlighting the working departments, responsibilities and experience of participants from CX.

\section{Insert Table 3 here}

$\mathrm{CY}$, by contrast, was a company comprising multiple smaller subsidiaries whose online activities included selling train tickets, processing payments and maintaining travel schedules for over 1.3 billion passengers. The online database of CY is considered one of the most significant in Europe. CY is responsible for managing its subsidiaries, selling online tickets and providing customer information. Table 4 includes the details of all participants from CY.

\section{Insert Table 4 here}

CZ provided interviews with employees working in both technical and non-technical departments. The company provides services and consultancy to retailing companies and their customers. Since it started in 2008 as a contact centre, they have supplied services and consultancy to more than 200,000 client companies and customers. All interviews were faceto-face in CZ. Table 5 lists the participants.

\section{Insert Table 5 here}

This study considered the knowledge enablers required for effective individual staff learning for the efficient process of KS to prevent ID theft in OROs (see Fig. 2). These include KM infrastructure, information communication technology (ICT) capabilities and training, job 
rotation, feedback on performance evaluation, information sourcing opportunities, leadership support and KS culture. Table 7 highlights the required knowledge enablers to share organisational knowledge. This study identifies the weaknesses in individual learning processes of KS to prevent ID theft. This section includes the cross-case analysis of the case studies. Moreover, it presents the results of the data analysis and offers solutions for efficient learning of individual employees for a successful KS process to prevent ID theft. The following subsections include the knowledge enablers required for individual staff learning for ID theft prevention KS. Weaknesses are identified, and solutions offered for enhancing the individual staff learning process of KS in OROs.

\section{1. $\quad \mathrm{KM}$ infrastructure}

The researchers identified various KS tools in the respondent companies. For example, CX has a robust infrastructure for ID theft prevention, and individual employees employed various KS tools, such as Yammer, CIFAS, AQAFAX and KBA. The company used an e-learning system, which provided information on available training to staff. Employees reported their activities on the system. CY also employed multiple tools to share knowledge among employees; including Yammer, a centralised system they call 'Connect', SharePoint 2007, emails, an elearning system, and LYNC. CZ used various tools to share knowledge among employees including Yammer, emails and an e-learning system. In addition, they uploaded policy documents on the company website. Individual employees were satisfied with the existing KM infrastructure. The resources required for them to perform their job roles were available, and they were satisfied with the usage of the existing resources. However, the existing KS tools were not being effective exploited for individual staff learning to share knowledge of ID theft prevention (Wenger et al., 2002; Iqbal et al., 2015). Employees were not obtaining advantage from existing systems to enhance their knowledge to prevent ID theft. The following quotes are illustrative:

"We need to know about identity theft issues and how to prevent them." (CZ-R06)

"I am not sure what resource is used to prevent our identities being stolen." (CY-R09)

"I am really happy with the IT systems available here; there are so many layers which help to avoid security issues. We have a good knowledge sharing system too, but these systems are not used for ID theft prevention." (CZ-R03)

The participant responses highlight that companies are not providing sufficient knowledge to staff regarding the identification of ID theft issues and how to employ existing resources to ensure prevention. A KS system is required so that employees can collectively and effectively share knowledge and learn from others' experiences to prevent ID theft. Therefore, ORO should design and implement an adequate KM infrastructure for ID theft prevention KS and learning.

\subsection{ICT Know-how and training}

The ICT infrastructure plays a key role in KS among the individuals within and outside an organisation (Omar Sharifuddin Syed-Ikhsan and Rowland, 2004). It is essential to understand the ICT skills required to assess the ability of staff to use those skills to solve the complicated problems of information management, knowledge transfer and presentations (Cobo, 2013). 
Moreover, it also includes learning and technical skills such as developing ideas, sharing information and fact-finding (Cobo, 2013). Employees require particular practical skills ('know-how') to perform tasks efficiently (Tsohou et al., 2012). These can be learned and developed through independent learning or detecting and emulating the skills of others, which are the approaches of a tacit KS environment (Letmathe et al., 2012; Prasarnphanich et al., 2016). This study found all three case studies provided minimal basic training to new employees. The cases typically provided relevant basic training for staff for their employment roles and the tools they require for work. However, there was no specific training available to employees for ID theft prevention awareness in any of the case studies, particularly for employees working in non-technical departments. All case studies provided minimal basic training to new employees. The following quotes are illustrative:

"...someone will show us a new way of working and a new way of pulling information out, and we will just take them on board." (CX-R07)

"When you join the company usually you have an induction to the building and the culture of the institution as a whole ... and there are also departmental inductions. Also within the job role then you get your specific training depending on your job role." (CY-R07)

"When I joined the company they provided training about the infrastructure, the way I work and how to deal with others in groups or the working environment. "(CZ-R02)

The quotes highlight companies are providing training to their staff for their job roles and the tools they require in the workplace as illustrated by the following quotes:

"We have had Excel training, spreadsheets, Access database training, things that we would need to produce our reports to the regional loss prevention managers. "(CXRR09)

"Guess that would be things like getting trained to know how to use the shared folders, to know how to use the shared software, and sometimes it is purchasing software as well that you need the training to be able to do."(CYR01)

The above quotations demonstrate that CX provides technical training to their staff in the fraud prevention and information security departments, whereas staff from the information security and the IT security departments of CY have technical know-how regarding ID theft issues and its prevention. None of these case studies provides training regarding sharing knowledge of ID theft prevention within their organisation. One respondent stated:

"...we are not doing anything like that; we do not need training for sharing the knowledge of ID theft prevention." (CX-R04)

$\mathrm{CY}$ is not focusing on enhancing the knowledge of individual staff for ID theft issues and their prevention, and how to share such knowledge. The literature illustrates that training is a learning opportunity to enhance technological skills for computer usage and KS (Hortovanyi and Ferincz, 2015), and therefore, organisations offer various training opportunities to their employees to keep their knowledge current (Dymock and McCarthy, 2006; Jones et al., 2013) for ID theft prevention. Consequently, organisations should design a comprehensive ICT training programme to educate their staff to share ID theft prevention knowledge effectively.

\subsection{Job rotation}


This study found that all the case studies should introduce a job rotation system to enhance employees knowledge to help prevent ID theft. Knowledge sharing among individuals is concerned with effectively establishing communication among employees inside the organisation. The most significant issue of $\mathrm{KS}$ is the trust within the organisation (Hashim and Tan, 2015; Bălău and Utz, 2016). For example, how willing are individuals to share their knowledge? Answering these questions leads us to activities based on trust building, team creation, job rotation and so forth (Sveiby, 2001). In CX there was no process for job rotation. A participant responded:

\section{"We do not do any job rotation really with anybody else." (CX-R11)}

Due to not having a policy of job rotation in CX, staff were not learning from others' experiences and had no chance to acquire knowledge from other departments. Staff had to self-learn from training. By contrast, $\mathrm{CY}$ has an active process of job rotation. All participants responded with "Yes" to the enquiry regarding job rotation as all staff undergo job rotation. Newly appointed staff are provided with training and move into different departments during their probationary period. While investigating the advantages of job rotation to enhance the knowledge of individual staff, this study found that OROs do not typically rotate the jobs of individuals for enhancing individual staff members to prevent ID theft in the company. The literature demonstrates that job rotation plays a vital role in enhancing knowledge of individual employees and teams within and outside any department (Ortega, 2001; Huang and Pan, 2014; Aga et al., 2016). Therefore, it is useful in enhancing the KS process to prevent ID theft in the organisation, and individual employees can gain an advantage. In $\mathrm{C} \mathrm{Z}$, there is no job rotation, some participants were not even aware of it:

\section{"I do not know about the job rotation."(CZ-R03) \\ "We do not have any process of job rotation in the company."(CZ-R06)}

By contrast, $\mathrm{CY}$ offered a system of job rotation where employees were gaining the advantage of experiencing a new environment; they learned from the experiences of others operating in different teams and groups from other departments. However, the existing job rotation process is typically not used as a learning resource for individual KS to prevent ID theft. Alternatively, $\mathrm{CX}$ and $\mathrm{CZ}$ do not have a culture of job rotation and staff learn from acquiring their experience by using the systems. As discussed previously, job rotation plays a vital role in enhancing the knowledge of staff working in different departments (Kane et al., 2005).

\subsection{Feedback on performance evaluation}

Developments in information technology are evolving the sophistication of employee performance monitoring (Alder and Ambrose, 2005). Feedback is vital for the evaluation and monitoring of activities of employees and is provided for various purposes namely: bringing the outcomes of activities or processes into focus; providing information when employees move away from primary goals; helping to identify new organisational goals or adjusting existing goals and guidance to perform activities. Feedback also promotes critical reflection and enables new approaches to occur (Gabelica et al., 2012). The following participants quotes indicate that all the case study organisations evaluate staff performance. Managers held monthly meetings with employees providing them with evaluator feedback:

"Our company checks the performance of all staff and provide feedback to everyone" (CXR04) 


\author{
"Yes, managers arrange monthly meetings and check our performance" (CY-R11) \\ “... we have evaluation processes here” (CZ-R06)
}

However, this study did not identify a feedback process on performance evaluation for KS to prevent ID theft in any of the case studies. The organisations are required to implement an employee evaluation process on learning ID theft prevention KS and provide feedback to individual employees.

\title{
4.5. Information sourcing opportunities
}

It is essential for any organisation to consider the availability of information sourcing opportunities necessary for an efficient employee learning process for successful KS (Holsapple, 2013). Effective procedures for enabling organisational learning or knowledge available by expediting knowledge transfer and sharing it among the skilled workforce are essential (Bhatt et al., 2010). Information sourcing opportunities or ease of gaining information is essential to ID theft prevention KS among employees. Consistent contact or communication networks with proficient information or a degree of technical and professional knowledge that is obtainable and available to individuals are examples of information sourcing opportunities.

All three OROs provide different information sourcing opportunities to their employees to share required knowledge with others within the working environment. However, the OROs are not focusing on the awareness of individual employees for enhancing the knowledge of ID theft issues and its prevention. Existing information sources can be used for sharing the knowledge of ID theft prevention inside the OROs. Employees can avail themselves of these opportunities to enhance their knowledge of ID theft identification and its prevention. Therefore, it is a weakness in ORO. OROs are required to provide an environment to utilise existing information sourcing opportunities for employee education and provide systems to efficiently share ID theft prevention knowledge with staff.

\subsection{Leadership support}

The literature highlights that leadership plays a vital role in managing the KS process in any organisation and provides awareness to staff for efficient KS (Bass and Stogdill, 1990; Nazareth and Choi, 2014). It is accountable for practising strategic planning for optimum use of resources and promoting a learning culture and KS (Boerner et al., 2007). This study found a supportive leadership in the researched OROs, where employees were satisfied with their management. However, the management of the OROs does not have any policies for enhancing employee knowledge regarding how to share information about ID theft prevention. This study did not identify evidence of leadership support for implementing a learning environment enabling employees to share knowledge of ID theft prevention. Due to the growth in ID theft crimes, there is an urgent requirement to design a policy for an individual staff learning process to enhance a KS environment to stop ID theft crimes. Leadership support is required to develop an educational environment for enhancing the knowledge of ID theft prevention and sharing knowledge within organisations. Furthermore, employees require leadership support to share their knowledge of ID theft prevention in OROs effectively. 


\subsection{Knowledge sharing culture}

Stoddart (2001), suggests KS can work if the culture of the organisation is supportive and changes are required to be implemented according to the culture of the organisation. Having an ineffective culture causes barriers to the individual KS process. Therefore, the process needs to be efficiently managed for an efficient KS process within OROs. This study found that both $\mathrm{CX}$ and $\mathrm{CZ}$ have a KS culture at the departmental level and staff members are trusted. However, individual staff are not ready to share their knowledge with others outside their department. The CY found an active culture of KS where employees are ready to share their knowledge with anybody employed in the organisation. However, there is no culture of KS to prevent ID theft in CY. This study found that no learning culture for KS to prevent ID theft. Therefore, OROs need to develop a culture of KS to prevent ID theft at inter-departmental level. The trust of other employees working in non-technical departments should be increased to include learning about ID theft prevention KS processes.

\section{Discussion}

The literature review did not discover evidence of prior research investigating the learning process of individual employees to share knowledge of ID theft prevention. This study investigates the learning processes of staff to disseminate knowledge of organisation ID theft prevention and to extend the KS framework proposed by Chong et al. (2011) to improve individual staff KS processes. Thus the authors evaluated how individual staff learn the effective KS techniques to prevent ORO ID theft. Namely, what are the weaknesses in the individual learning environment within OROs? Moreover, how to enhance the learning environment and the process of KS to prevent ID theft? Various frameworks in the area of ID theft prevention and KS were evaluated under the following criteria:

1. Functionality: the framework should be capable of fulfilling the research objectives of functioning.

2. Comprehensiveness: covers the factors of KS but not overly complicated.

3. Adaptability: frameworks must be flexible and modifiable for an alternate purpose.

4. Ongoing improvement: focus on ongoing improvements to enable organisation KS.

5. Empirically derived: be empirically derived from previous research.

6. Focused components: include components focusing on the research.

By comparing and contrasting (see Table 6), a KS framework proposed by Chong et al. (2011) was adopted for extension in the context of staff KS to prevent ID theft in the ORO. The guiding framework has previously been applied in other industries in the context of KS.

\section{Insert Table 6 here}

\section{Insert Table 7 here}

Table 7 summarises the knowledge enablers required for employees learning to share the knowledge of ID theft prevention in OROs. It includes literature findings for the requirements of KS enablers for the learning of individual staff working in the OROs and the availability and use of these enablers by employees. It also includes recommendations for an enhanced 
learning process of KS to prevent ID theft. This study identified various ways in which individuals share knowledge. Results demonstrate that employees use different methods of communication; including, email and a corporate social networking system called 'Yammer'.

Furthermore, the researched OROs have their KS environment, such as CX uses a page they call 'Blackboard' where they post updates for individuals. A participant from CX responded that "we have blackboard where people post the information" $(C X-R 11)$, and CY uses SharePoint 2007 and an e-portal to disseminate information. Participant CY noted, "we share information via SharePoint and also use e-portal for general discussions"(CY-R04).

The findings highlight that participating OROs have different learning procedures for individuals; for example, they arrange inductions for newcomers, have scheduled training programmes and seminars. These learning opportunities are being provided to individuals for know-how and awareness raising of the working environment and usage of existing facilities including the IT infrastructure and working procedures (CX-R02, CY-R10 and CZ-R07). However, the results identify that real learning opportunities are not being used concerning the awareness of ID theft prevention KS (CX-R02, CY-R10 and CZ-R07). Participants in all OROs responded as;

"Our company does not provide the information about identity theft knowledge sharing" (CX$\mathrm{R} 02$ )

"It not in my knowledge that we share the knowledge of information theft prevention. I think our organisation should provide it" (CY-R10)

Staff need to know how to protect the personal and organisational information, so I commend for its sharing with us" (CZ-R07)

Individual staff in OROs require a learning environment for sharing the knowledge of ID theft prevention. The literature review found that $\mathrm{KS}$ is the primary source for enhancing staff awareness (Abdullah et al., 2016). This study suggests that staff working in OROs may be provided with various learning opportunities of ID theft prevention within the organisation, such as training, seminars, learning courses and refresher events for an enhanced awareness for enabling a KS process to prevent ID theft.

The findings show that CY was open to conversation and sharing the knowledge of individuals within and outside their departments. However, the staff from $\mathrm{CX}$ and $\mathrm{CZ}$ shared their information with others within their departments. However, they were reluctant to share their information with staff outside their working departments. Consequently, staff working in nontechnical departments were not aware of ID theft issues.

The results demonstrate that the staff working in non-technical departments operated with business and customer data; for example, staff working in the accounts department managed the financial details of businesses and customers, customer services advisors deal with the customers and their personal information. Respondents noted:

"In other units of business people are working here but we do not discuss them about ID theft" (CX-R10)

"We have a financial process, and people are working in the finance department" (CY-R01)

"Yes we deal with the customers via telephone calls discuss their information to resolve their issues" (CZ-R05)

This study found staff from technical departments such as IT, information security and fraud prevention, typically do not share knowledge of ID theft prevention and its awareness with staff working in non-technical departments. To effectively manage customers and prevent 
customer and data from ID fraudsters, organisations should develop a learning environment for improved awareness of OROs staff.

As discussed in section 4.6, the organisation leadership was supportive throughout the case companies; they were communicating effectively with staff through emails, telephone and meetings. At the departmental level, managers arranged staff meetings to discuss progress and working tasks. Line managers communicated regularly with individual employees and discussed issues with them. Individual employees received feedback from management teams through emails and one-to-one meetings. However, no evidence of leadership support for an individual staff-learning environment to share the knowledge of ID theft prevention within the organisations was apparent (CX-R08, CY-R02 and CZ-01). As previously discussed, leadership plays a key role in developing the organisational culture. Therefore, the support of leadership is required for the development of a learning environment and KS culture to provide awareness to individual staff for ID theft identification and its prevention. The individual staff from information security and fraud prevention departments share their knowledge of ID theft prevention in $\mathrm{CX}$ and $\mathrm{CZ}$. However, there was no KS process to prevent ID theft between individuals in non-technical departments.

Furthermore, this study found that existing learning opportunities are not being used to enhance the knowledge of individuals. OROs are required to increase trust levels among staff regarding efficiently sharing their knowledge of ID theft prevention. Individuals are required to enhance their knowledge of the knowledge transfer process to prevent ID theft. The OROs need to develop an effective educational system to enhance the knowledge of their employees in ID theft prevention KS. The OROs disseminate some policy documents to employees on ID theft prevention, which set out awareness of confidential information, but typically these documents do not describe KS for ID theft prevention. Employees use e-mails to share their knowledge of their working activities.

Moreover, there is no job rotation strategy or system for enhancing the knowledge of employees regarding ID theft prevention. Employees are learning from their own experience in information security related departments, which is time-consuming and also potentially resource intensive. By contrast, case study $\mathrm{CY}$ evidenced a job rotation process, but it was not being used to enhance the knowledge of staff to prevent ID theft. Job rotation in the organisation is essential to enhance employee knowledge. Thus, OROs should seek to efficiently rotate the knowledge holders' jobs around different teams across all departments to enhance their knowledge of other employees regarding ID theft prevention.

This study found that there is no learning process for employees working in non-technical departments. They typically deal with customer and organisational data, and due to not having an awareness of ID theft issues and protection from ID theft, there is a higher likelihood of data being stolen.

Employees trust others within their department and share knowledge with them regarding preventing ID theft. The OROs need to enhance the individual staff trust levels across departments for ID theft prevention KS, to share the knowledge so that employees with limited or no knowledge can learn how to protect personal and organisational information. The support of the leadership is required for developing employee learning concerning KS to prevent ID theft. Employees require effective and systematic staff training in KS processes to prevent ID theft.

This study aids OROs to enhance the process of KS to prevent ID theft and offers solutions regarding developing an effective KS culture. It also assists organisations to develop an effective training system to educate their staff to share their knowledge of ID theft prevention. 
This study contributes to the existing knowledge by providing an extended framework for individual staff KS processes to prevent ID theft within OROs.

Moreover, it fills the knowledge gap by investigating individual staff learning processes of KS to prevent ID theft in OROs and implement an agile learning process, which adds knowledge to the field of KS and ID theft prevention. It identified new knowledge enablers that are required for a learning environment for an enhanced KS process to prevent ID theft in organisations. The study identified the weaknesses in individual staff members' learning for ID theft prevention KS to prevent ID theft. The steps required for an efficient individual staff learning process to enhance their knowledge of ID theft prevention and its dissemination within an organisation are also considered.

The study contributes to ORO by identifying the weaknesses of such organisations in individual staff learning regarding efficient KS processes to prevent ID theft. It recommends guidance to develop an educational environment for disseminating knowledge of ID theft prevention and how to share it with staff. This study guides the leadership regarding managing existing resources for an effective learning environment for KS to prevent ID theft in their companies and making effective policies for individual staff $\mathrm{KS}$.

\section{Theoretical Contributions and Practical Implications}

After evaluating KS and ID theft prevention literature and identifying an appropriate theoretical framework for an extension, the Chong et al. (2011) framework was selected as the guiding framework (see Fig. 1). The framework was adopted for extension in the ORO context. The framework was previously used by Chong et al. (2011) for KM implementation in a public sector organisation. The Chong et al. (2011) framework was sufficiently comprehensive to investigate the KS process and capable of fulfilling the research objectives. Furthermore, the framework was flexible and modifiable as it encompassed the significant factors of KS and was not overly complicated to adopt. It was useful for ongoing improvements; for example, it enables individual staff KS within an organisation as it connects KM enablers and the process to share knowledge in a public-sector accounting organisation. The framework includes the components having a clear focus. It interconnects solutions of KM through culture, leadership, learning and technology to enhance a KS process in the organisations, which was the central focus of the study as it is the investigation of individual staff KS processes for ID theft prevention.

Moreover, it was effectively focused on ongoing improvements as it enables KS processes and is useful as a process of strategic KM which supports knowledge networks and knowledge flow to enhance the decision-making process in the organisations. The guiding framework highlighted in Fig. 1was not used to enhance KS processes for ID theft prevention and provide an agile learning environment of ID theft prevention before this study. Therefore, the framework has been extended in the context of improving KS processes for ID theft prevention within the OROs (see Fig.2).

The amendments in the guiding framework included the removal of unnecessary factors in the context of the present study. This study adds additional factors useful for effective KS processes for ID theft prevention in the context of OROs. Furthermore, significant and relevant factors were borrowed from the guiding framework to fulfil the requirements of this study (see Fig. 1); for example, job rotation, feedback on performance evaluation, information sourcing opportunities, leadership support, and a KS culture are adopted from the guiding framework. Fig. 2 includes an extended framework for KS processes to prevent ID theft in OROs. 


\section{Insert Fig. 2 here}

However, factors such as know-how and skills, job training, and learning opportunities were replaced by ICT know-how and training. The existing literature notes that employee training is used for the improvement of working procedures. Employment training is useful to enhance knowledge only in the workplace in the current organisation. Such training is provided to improve knowledge regarding organisational technology, and to understand internal workplace infrastructure and procedures, which can be provided to gain knowledge regarding characteristics of the products and customers of the organisation (De Grip and Sauermann, 2013).

\section{Insert Fig. 3 here}

Employees receive training according to the nature of their employment role and thus enhance their working knowledge and competencies which is out of the scope of this study. However, in the KS process for ID theft prevention, training is required to enhance KS processes for ID theft prevention. Therefore, the factor job training needs to be replaced with a new knowledge enabler which is useful for an effective KS process for ID theft prevention within the ORO. Furthermore, in the guiding framework, ICT know-how, job training and learning opportunities factors make it complicated and difficult to implement in the context of KS for ID theft prevention. During the investigation, the authors found that training was one of the learning opportunities required to enhance knowledge of individual staff members for KS for ID theft prevention within the organisation. Therefore, these factors cannot be separated to provide the knowledge for ID theft prevention and need to be replaced by a new factor of ICT know-how and training. Fig. 3 displays the amended framework with the replacement of unnecessary and complicated factors (ICT know-how, job training and learning opportunities) with ICT knowhow and training factor (new factor).

\section{Insert Fig. 4 here}

Furthermore, the guiding framework includes ICT infrastructure and software, and KM technologies factors. However, this study found that ICT infrastructure and software is a part of KM technologies and cannot be separated for KS for ID theft prevention. Having these separate factors in the framework makes it overly complicated for individuals to share their knowledge of ID theft prevention and needs to be substituted by a new factor which makes the framework easy to understand and implement to enhance KS processes for ID theft prevention. Therefore, the researchers replaced both factors with a new KM infrastructure factor. Fig.4 displays the amended framework.

This study contributes to investigating learning opportunities for employees to share knowledge of ID theft prevention within OROs. This study identifies a weakness in individual learning for KS to prevent ID theft within OROs, and also provides understanding of the need and availability of knowledge enablers required for ID theft prevention KS. The findings illustrate that there is no individual staff member's learning environment for KS to prevent ID theft in OROs. The knowledge of ID theft prevention is not shared among employees between OROs departments. Typically, employees share knowledge of ID theft prevention within their 
departments. Basic training is provided to new employees to allow them to utilise the organisation systems and working activities within the OROs. One organisation arranged seminars on ID theft prevention; however, the authors did not find any agile learning environment for sharing knowledge.

\section{Conclusions}

This study offers significant contributions regarding theory and practice. In terms of theory, the research extended the framework proposed by Chong et al. (2011) by using it in the new context of ID theft prevention. The guiding framework was extended by merging additional factors and producing two new factors. From the perspective of the practical implications, this study investigated OROs and provided solutions for improved KS processes for ID theft prevention. The extended framework can be adapted to enhance the knowledge of individuals in the ORO. The empirical research identifies the various weaknesses in KS for ID theft prevention and non-availability of agile learning processes to prevent ID theft within ORO. Finally, this study provides managers with useful guidelines for developing appropriate KS processes for ID theft prevention in the organisations, and to educate staff for effective KS.

The limitations of this study provide opportunities for future research. The findings are only based on three OROs in the UK and, therefore, further research is required using an empirical method and focusing on other areas such as banking and public sector organisations within and outside the UK. As it is limited to the use of the case study approach, future research would be strengthened by using quantitative research methods for testing the validity of the research outcomes. The generalisability of this study was based on three case studies with makes it limited to the findings of the case companies. Therefore, this research focus could be extended to a survey to increase the generalisability of the findings. The outcomes of this study recommend changing the KS culture of the organisations, and further investigation of the behavioural changes in employees caused by implementing the outcomes of this study is required. Furthermore, the study recommends further investigation, such as managerial practices to prevent ID theft, the impact of ID theft prevention KS on employees and an evaluation of the KS tools to prevent ID theft in an organisation.

\section{References}

Abdullah, M., Shah, M.H. and Ahmed, W. (2016), "Identity theft prevention in online retail organisations: a knowledge sharing framework". 4th International Academic Conference in Paris, 15-16th August 2016, Paris, France, pp. 71-85.

Aga, D.A., Noorderhaven, N. and Vallejo, B. (2016), "Transformational leadership and project success: the mediating role of team-building", International Journal of Project Management, Vol. 34 No. 5, pp. 806-818.

Aimeur, E. and Schonfeld, D. (2011), "The ultimate invasion of privacy: Identity theft", Ninth Annual International Conference on Privacy, Security and Trust, Concordia University Montreal, QC, Canada, 24-31, IEEE.

Alder, G.S. and Ambrose, M.L. (2005), "An examination of the effect of computerized 
performance monitoring feedback on monitoring fairness, performance, and satisfaction", Organizational Behaviour and Human Decision Processes, Vol. 97 No. 2, pp. 161-177.

Andrews, K.M. and Delahaye, B.L. (2000), "Influences on knowledge processes in organizational learning: the psychosocial filter", Journal of Management Studies, Vol. 37 No. 6, pp. 797-810.

Annosi, M.C., Hemphälä, J. and Brunetta, F. (2018), "Investigating the impact of agile methods on learning and innovation", in Boccardelli P., Annosi M., Brunetta F., Magnusson M. (Eds), Learning and Innovation in Hybrid Organizations (pp. 73-97). Palgrave Macmillan, Cham.

Bălău, N. and Utz, S. (2016), "Exposing information sharing as strategic behavior: power as responsibility and "trust" buttons", Journal of Applied Social Psychology, Vol. 46 No. 10, pp. 593-606.

Bass, B.M. and Stogdill, R.M. (1990), Bass \& Stogdill's handbook of leadership: theory, research, and managerial applications, ( ${ }^{\text {rd }}$ edn.) Simon and Schuster, London.

Bhatt, G., Emdad, A., Roberts, N. and Grover, V. (2010), "Building and leveraging information in dynamic environments: the role of IT infrastructure flexibility as enabler of organizational responsiveness and competitive advantage", Information \& Management, Vol. 47 No. 7, pp. 341-349.

Boerner, S., Eisenbeiss, S.A. and Griesser, D. (2007), "Follower behavior and organizational performance: the impact of transformational leaders", Journal of Leadership \& Organizational Studies, Vol. 13 No. 3, pp. 15-26.

Brantingham, P., Brantingham, P. and Kinney, B. (2017), "Criminology in Canada: the context of its Criminology", in Triplett, R.A. (Ed) The Handbook of the History and Philosophy of Criminology (pp. 360-376). John Wiley \& Sons, Hoboken, NJ, USA.

Bürgin, A. (2017), "Internal coordination and legitimation strategies: assessing the influence of individual commissioners in the policy formulation process", Journal of European Integration, Vol. 39 No. 1, pp. 1-15.

Chang, H.H. and Chuang, S.S. (2011), "Social capital and individual motivations on knowledge sharing: participant involvement as a moderator", Information \& Management, Vol. 48 No. 1, pp. 9-18.

CIFAS (2017). Fraudscape 2017, External and internal fraud threats - essential reading for fraud and financial crime strategists, available at https://www.cifas.org.uk/secure/contentPORT/uploads/documents/CIFAS\%20Reports/Extern al-Fraudscape \%20report\%202017.pdf accessed $20^{\text {th }}$ December 2018.

Chong, S.C., Salleh, K., Ahmed, S.N.S. and Sharifuddin, S.I.S. (2011), " KM implementation in a public sector accounting organization: an empirical investigation", Journal of Knowledge Management, Vol. 15 No. 3, pp. 497-512.

Chow, W.S. and Chan, L.S. (2008), "Social network, social trust and shared goals in organizational knowledge sharing", Information \& Management, Vol. 45 No. 7, pp. 458-465.

Cobo, C. (2013), "Skills for innovation: envisioning an education that prepares for the changing world", Curriculum Journal, Vol. 24 No. 1, pp. 67-85.

Conrad, E., Misenar, S., Feldman J. (2013), CISSP Study Guide, Elsevier, Waltham.

Creswell, J.W. (2003), Research design: qualitative, quantitative and mixed methods approaches, Thousand Oaks, CA: Sage Publications. 
David, S. (2004), Qualitative research: theory, method and practice (2 $\left.{ }^{\text {nd }} \mathrm{edn}\right)$, London, Sage Publicatons.

De Grip, A. and Sauermann, J. (2013), "The effect of training on productivity: the transfer of on-the-job training from the perspective of economics", Educational Research Review, Vol. 8 No. 1, pp. 28-36.

Dong, T.-P., Hung, C.L. and Cheng, N.C. (2016), "Enhancing knowledge sharing intention through the satisfactory context of continual service of knowledge management systems", Information Technology \& People, Vol. 29 No. 4, pp. 807-829.

Dymock, D. and McCarthy, C. (2006), "Towards a learning organization? Employee perceptions". The Learning Organization, Vol. 13 No. 5, pp. 525-537.

Eisenstein, E.M. (2008), "Identity theft: An exploratory study with implications for marketers". Journal of Business Research, Vol. 61 No. 11, pp. 1160-1172.

Eroglu, S.A., Machleit, K.A., and Davis, L.M. (2001), "Atmospheric qualities of online retailing: a conceptual model and implications". Journal of Business Research, Vol. 54, pp. 177-184.

Fennelly, L.J. (2004) Handbook of loss prevention and crime prevention, (4th edn), Butterworth-Heinemann, Burlington.

Fontana, R. M., Meyer Jr, V., Reinehr, S. and Malucelli, A. (2015), "Progressive outcomes: a framework for maturing in agile software development", Journal of Systems and Software, Vol. 102, pp. 88-108.

Gabelica, C., Van den Bossche, P., Segers, M. and Gijselaers, W. (2012), "Feedback, a powerful lever in teams: a review", Educational Research Review, Vol. 7 No. 2, pp. 123-144.

Gan, B., Menkhoff, T. and Smith, R. (2015), "Enhancing students' learning process through interactive digital media: new opportunities for collaborative learning", Computers in Human Behavior, Vol. 51, Part B, pp. 652-663.

Gandomani, T.J., Zulzalil, H., Ghani, A.A.., Sultan, A.B.M. and Sharif, K.Y. (2014), "How human aspects impress agile software development transition and adoption", International Journal of Software Engineering and Its Applications, Vol. 8 No. 1, pp. 129-148.

Ghauri, P. and Grønhaug, K. (2002), Research Methods in Business Studies: A Practical Guide. Harlow: FT Prentice-Hall.

Gillham, B. (2000), Developing a Questionaire, London \& New York: Continum.

Grant, R.M. and Baden-Fuller, C. (2004), "A knowledge accessing theory of strategic alliances", Journal of Management Studies, Vol. 41 No. 1, pp. 61-84.

Gray, J. and Laidlaw, H. (2002), "Part-time employment and communication satisfaction in an Australian retail organisation", Employee Relations, Vol. 24 No. 2, pp. 211-228.

Grover, A., Berghel, H. and Cobb, D. (2011), "The state of the art in identity theft", in Zelkowitz, M.V (Ed.) Advances in Computers, Vol. 83 Chapter 1 pp. 1-50.

Hashim, K.F. and Tan, F.B. (2015), "The mediating role of trust and commitment on members? continuous knowledge sharing intention: a commitment-trust theory perspective", International Journal of Information Management, Vol. 35 No. 2, pp. 145-151.

He, W. and Wei, K.-K. (2009), "What drives continued knowledge sharing? An investigation of knowledge-contribution and-seeking beliefs", Decision Support Systems, Vol. 46 No. 4, pp. $826-838$. 
Henttonen, K., Kianto, A. and Ritala, P. (2016), "Knowledge sharing and individual work performance: an empirical study of a public sector organisation", Journal of Knowledge Management, Vol. 20 No. 4, pp. 749-768.

Hill, J. and Tiu Wright, L. (2001), "A qualitative research agenda for small to medium sized enterprises", Marketing Intelligence and Planning, Vol. 19 No. 6, pp. 432-443.

Holsapple, C. (2013), Handbook on knowledge management 1: Knowledge matters. Heidelberg, USA, Springer Science \& Business Media.

Hortovanyi, L. and Ferincz, A. (2015), "The impact of ICT on learning on-the-job", The Learning Organization, Vol. 22 No. 1, pp. 2-13.

Huang, K. (2014), "Knowledge Sharing in a Third?Party? Governed Health and Human Services Network", Public Administration Review, Vol. 74 No. 5, pp. 587-598.

Huang, S.-H. and Pan, Y.-C. (2014), "Ergonomic job rotation strategy based on an automated RGB-D anthropometric measuring system", Journal of Manufacturing Systems, Vol. 33 No. 4, pp. 699-710.

Iqbal, S., Toulson, P. and Tweed, D. (2015), "Employees as performers in knowledge intensive firms: role of knowledge sharing". International Journal of Manpower, Vol. 36 No. 7, pp. 1072-1094.

Jones, P., Beynon, M.J., Pickernell, D. and Packham G. (2013), "Evaluating the impact of different training methods on SME business performance", Environment and Planning $C$ Government and Policy, Vol. 31 No. 1, pp. 56-81.

Jones, P., Simmons, G., Packham, G., Beynon-Davies, P. and Pickernell, D. (2014), "An exploration of the attitudes and strategic responses of soleproprietor micro-enterprises in adopting information and communication technology", International Small Business Journal, Vol. 32 No. 3, pp. 285-306.

Kane, A.A., Argote, L. and Levine, J.M. (2005), "Knowledge transfer between groups via personnel rotation: Effects of social identity and knowledge quality", Organizational Behavior and Human Decision Processes, Vol. 96 No. 1, pp. 56-71.

Kane, G.C. (2017), "The evolutionary implications of social media for organizational knowledge management", Information and Organization, Vol. 27 No. 1, pp. 37-46.

Kim, S. and Lee, H. (2006), "The impact of organizational context and information technology on employee knowledge?sharing capabilities", Public Administration Review, Vol. 66 No. 3, pp. 370-385.

Kowta Sita, N.K. and Chitale, C.M. (2012), "Collaborative knowledge sharing strategy to enhance organizational learning", Journal of Management Development, Vol. 31 No. 3, pp. $308-322$.

Kropp, M., Meier, A., Mateescu, M. and Zahn, C. (2014), Teaching and learning agile collaboration. In Software Engineering Education and Training (CSEE\&T), 2014 IEEE 27th Conference on (pp. 139-148). Graz, Austria, IEEE.

Lai, J., Lui, S.S. and Tsang, E.W.K. (2016), "Intrafirm knowledge transfer and employee innovative behavior: the role of total and balanced knowledge flows", Journal of Product Innovation Management, Vol. 33 No. 1, pp. 90-103.

Letmathe, P., Schweitzer, M. and Zielinski, M. (2012), "How to learn new tasks: Shop floor performance effects of knowledge transfer and performance feedback", Journal of 
Operations Management, Vol. 30 No. 3, pp. 221-236.

Levy. M. and Powell, P. (2000), "Information systems strategy for small and medium sized enterprises: an organisational perspective", Journal of Strategic Information Systems, Vol. 9 No. 1, pp. 63-84.

Lu, L., Leung, K. and Koch, P.T. (2006), "Managerial knowledge sharing: the role of individual, interpersonal, and organizational factors", Management and Organization Review, Vol. 2 No. 1, pp. 15-41.

Luen, T.W. and Al-Hawamdeh, S. (2001), "Knowledge management in the public sector: principles and practices in police work", Journal of Information Science, Vol. 27 No. 5, pp. 311-318.

Madiwalar, M.B. (2016), "Privacy rights and data protection in cyber space with special reference to E-Commerce, Global Journal For Research Analysis, Vol. 145 No. 3, pp. 11 18.

Merriam, S.B. (2001), "Andragogy and self-directed learning: pillars of adult learning theory, New Directions for Adult and Continuing Education, Vol. 89, pp. 3-13.

Miles, M. and Huberman, A. (1994), Qualitative data analysis: an expanded sourcebook (2nd edn). London: Sage.

Nazareth, D.L. and Choi, J. (2014), "A system dynamics model for information security management", Information \& Management, Vol. 52 No. 1, pp. 123-134.

Noguera, I., Guerrero-Roldán, A.-E. and Masó, R. (2018), "Collaborative agile learning in online environments: strategies for improving team regulation and project management", Computers \& Education, Vol. 116, pp. 110-129.

Nonaka, I. and Peltokorpi, V. (2006), "Objectivity and subjectivity in knowledge management: a review of 20 top articles", Knowledge and Process Management, Vol. 13 No. 2, pp. 73-82.

Omar Sharifuddin Syed-Ikhsan, S. and Rowland, F. (2004), "Knowledge management in a public organization: a study on the relationship between organizational elements and the performance of knowledge transfer", Journal of Knowledge Management, Vol. 8 No. 2, pp. 95-111.

Ortega, J. (2001), "Job rotation as a learning mechanism", Management Science, Vol. 47 No. 10, pp, 1361-1370.

Park, S. and Kim, E.J. (2018), "Fostering organizational learning through leadership and knowledge sharing", Journal of Knowledge Management. Vol. 22 No. 6, pp. 1408-1423.

Pee, L.G. and Min, J. (2017), "Employees' online knowledge sharing: The effects of personenvironment fit", Journal of Knowledge Management, Vol 21 No 2, pp. 432-453.

Perry, C. (1998), "Processes of a case study methodology for postgraduate research in marketing", European Journal of Marketing, 32(9/10), pp. 785-802.

Prasarnphanich, P., Janz, B.D. and Patel, J. (2016), "Towards a better understanding of system analysts' tacit knowledge: a mixed method approach", Information Technology \& People, Vol. 29 No. 1, pp. 69-98.

Real, J.C., Roldán, J.L. and Leal, A. (2014), "From entrepreneurial orientation and learning orientation to business performance: analysing the mediating role of organizational learning 
and the moderating effects of organizational size", British Journal of Management, Vol. 25 No. 2, pp. 186-208.

Sedighi, M., Lukosch, S., Brazier, F., Hamedi, M. and van Beers, C. (2018), "Multi-level knowledge sharing: the role of perceived benefits in different visibility levels of knowledge exchange", Journal of Knowledge Management, available at https://doi.org/10.1108/JKM09-2016-0398 (accessed 20 th December 2018).

Serenko, A. and Bontis, N. (2016), "Negotiate, reciprocate, or cooperate? The impact of exchange modes on inter-employee knowledge sharing", Journal of Knowledge Management, Vol. 20 No. 4, pp. 687-712.

Silvi, R. and Cuganesan, S. (2006), "Investigating the management of knowledge for competitive advantage: a strategic cost management perspective", Journal of Intellectual Capital, Vol. 7 No. 3, pp. 309-323.

Singh Sandhu, M., Jain, K. and Ahmad, I. (2011), "Knowledge sharing among public sector employees: evidence from Malaysia", International Journal of Public Sector Management, Vol. 24 No. 3, pp. 206-226.

Siong, C.C., Salleh, K., Ahmad, S.N.S and Sharifuddin, S.-I.S.O (2011), "KM implementation in a public sector accounting organization: an empirical investigation, Journal of Knowledge Management, Vol. 15 No. 3, pp. 497-512.

Smith, N. (1991), "The case-study: A vital yet misunderstood research method". In: Smith, N. and Stake, R, (eds) The Art of Case Study Research (pp.145-158). London: Sage.

Stenmark, D. (2000), "Leveraging tacit organizational knowledge", Journal of Management Information Systems, Vol. 17 No. 3, pp. 9-24.

Stoddart, L. (2001), "Managing intranets to encourage knowledge sharing: opportunities and constraints", Online Information Review, Vol. 25 No. 1, pp. 19-29.

Strauss, A.J. and Corbin, J. (1998), Basis of qualitative research: Techniques and procedures for developing grounded theory (2nd ed.), Thousand Oaks, CA: Sage Publications.

Sveiby, K. (2001), "A knowledge-based theory of the firm to guide in strategy formulation", Journal of Intellectual Capital, Vol. 2 No. 4, pp. 344-358.

Titi Amayah, A. (2013), "Determinants of knowledge sharing in a public sector organization", Journal of Knowledge Management, Vol. 17 No. 3, pp. 454-471.

Tohidinia, Z. and Mosakhani, M. (2010), "Knowledge sharing behaviour and its predictors". Industrial Management \& Data Systems, Vol. 110 No. 4, pp. 611-631.

Tsohou, A., Karyda, M., Kokolakis, S. and Kiountouzis, E. (2012), "Analyzing trajectories of information security awareness. Information Technology \& People, Vol. 25 No. 3, pp. $327-352$.

Uden, L. and He, W. (2017), "How the internet of things can help knowledge management: a case study from the automotive domain", Journal of Knowledge Management, Vol. 21 No. 1, pp. 57-70.

Wang, S., Noe, R.A., and Wang, Z.-M. (2014), "Motivating Knowledge Sharing in Knowledge Management Systems: A Quasi Field Experiment", Journal of Management, Vol. 40 No. 4, pp. 978-1009.

Wang, W. and Hou, Y. (2015), "Motivations of employees' knowledge sharing behaviors: a 
self-determination perspective", Information and Organization, Vol. 25 No. 1, pp. 1-26.

Wenger, E., McDermott, R.A. and Snyder, W. (2002), Cultivating communities of practice: a guide to managing knowledge, Boston, Harvard Business Press.

Willem, A. and Buelens, M. (2007), "Knowledge sharing in public sector organizations: the effect of organizational characteristics on interdepartmental knowledge sharing", Journal of Public Administration Research and Theory, Vol. 17 No. 4, pp. 581-606.

Wiredu, G.O. (2012), "Information systems innovation in public organisations: an institutional perspective", Information Technology \& People, Vol. 25 No. 2, pp. 188-206.

Xiong, J., Tang, Y. and Medlin, D.B. (2018), Analysis of agile learning into information systems project class: a cognitive apprenticeship approach. Proceedings of the Appalachian Research in Business Symposium, East Tennessee State University, March 22-23.

Yang, J.-T. (2007), "Knowledge sharing: investigating appropriate leadership roles and collaborative culture", Tourism Management, Vol. 28 No. 2, pp. 530-543.

Yao, L.J., Kam, T.H.Y. and Chan, S.H. (2007), "Knowledge sharing in Asian public administration sector: the case of Hong Kong", Journal of Enterprise Information Management, Vol. 20 No. 1, pp. 51-69.

Yildirim, E. (2016), The importance of information security awareness for the success of business enterprises. Advances in Human Factors in Cybersecurity. Cham, Springer International Publishing.

Yin, R.K. (2015), Qualitative Research from Start to Finish (2 ${ }^{\text {nd }}$ edn), London, Guilford Publications.

Zaeem, R.N., Manoharan, M., Yang, Y. and Barber, K.S. (2017), "Modeling and analysis of identity threat behaviors through text mining of identity theft stories", Computers \& Security, Vol. 65, pp. 50-63.

Zhu, Y.Q., Chiu, H. and Infante Holguin-Veras, E.J. (2018), "It is more blessed to give than to receive: examining the impact of knowledge sharing on sharers and recipients", Journal of Knowledge Management, Vol. 22 No. 1, pp. 76-91. 
Table 1. The need for individual staff learning in the KS process to prevent ID theft

\begin{tabular}{|c|c|}
\hline Literature Findings & Source(s) \\
\hline $\begin{array}{l}\text { - Knowledge is an essential resource for companies. } \\
\text { - } \quad \text { Individual staff members' KS is vital for organisations. } \\
\text { - The ability of an organisation to use knowledge effectively } \\
\text { and extensively depends on its individuals who primarily } \\
\text { create, use and share the knowledge. } \\
\text { - Individual staff are required to learn how to share the } \\
\text { knowledge of ID theft prevention. }\end{array}$ & $\begin{array}{l}\text { Abdullah et al., (2016), } \\
\text { Henttonen et al., (2016), Wang } \\
\text { and Hou (2015), Huang (2014), } \\
\text { Kowta Sita and C.M. Chitale } \\
\text { (2012), Luen and Al-Hawamdeh } \\
\text { (2001), Siong et al., (2011), } \\
\text { Singh et al., (2011), Jen-te Yang } \\
\text { (2007), Willem and Buelens } \\
\text { (2007), Nonaka and Peltokorpi } \\
\text { (2006), and Kane et al., (2005) }\end{array}$ \\
\hline $\begin{array}{l}\text { - Managing the knowledge and sharing it is known to be a big } \\
\text { challenge in the private sector. The organisations are required } \\
\text { to provide awareness to the staff of the KS process. }\end{array}$ & $\begin{array}{l}\text { Kim and Lee (2006), and Silvi } \\
\text { and Cuganesan (2006) }\end{array}$ \\
\hline $\begin{array}{l}\text { - In organisations, the role of individuals in KS needs } \\
\text { consideration. } \\
\text { - A higher level of attention to the people's viewpoint of } \\
\text { knowledge in the organisations is required. }\end{array}$ & $\begin{array}{l}\text { Grant and Baden-Fuller (2004), } \\
\text { and Stenmark (2000) }\end{array}$ \\
\hline $\begin{array}{l}\text { - Successful KS is dependent on the connections between } \\
\text { individuals in the company. } \\
\text { - There is rising empirical proof of focusing on the importance } \\
\text { of individuals and their related aspects in KS processes in } \\
\text { organisations. }\end{array}$ & $\begin{array}{l}\text { Iqbal et al., (2015), Andrews and } \\
\text { Delahaye (2000), and Wenger } \text { et } \\
\text { al., (2002) }\end{array}$ \\
\hline $\begin{array}{l}\text { - } \quad \text { Various studies accept that KS activities are encouraged and } \\
\text { implemented, particularly at an individual level. } \\
\text { - Employee learning environment supports individuals for } \\
\text { KSof the companies. }\end{array}$ & $\begin{array}{l}\text { Chang and Chuang (2011), Chow } \\
\text { and Chan (2008), Cabrera and } \\
\text { Cabrera (2002), and Bock and } \\
\text { Kim (2001) }\end{array}$ \\
\hline $\begin{array}{l}\text { - Research studies include the drivers of individual KS in } \\
\text { organisations. }\end{array}$ & $\begin{array}{l}\text { Chang and Chuang (2011), } \\
\text { Tohidinia and Mosakhani (2010), } \\
\text { and Chow and Chan (2008) }\end{array}$ \\
\hline $\begin{array}{l}\text { - Comprehensible attention to the aspects affecting KS in } \\
\text { relation to individual level performance still seems to be } \\
\text { missing in organisations. }\end{array}$ & Lu et al., (2006) \\
\hline $\begin{array}{l}\text { - } \quad \text { The gap in the existing research is highlighted. } \\
\text { - } \\
\text { Research studies claimed that earlier studies tended to } \\
\text { neglect the connections between the approach leading to the } \\
\text { focus on individual KS and the environment of enhancing the } \\
\text { knowledge of individuals working in online retail companies. }\end{array}$ & $\begin{array}{l}\text { Lai et al., (2016), Yildirim } \\
\text { (2016), He and Wei (2009) }\end{array}$ \\
\hline $\begin{array}{l}\text { - Most research on sharing knowledge focuses on public sector } \\
\text { organisations. }\end{array}$ & $\begin{array}{l}\text { Titi Amayah (2013), Singh } \\
\text { Sandhu et al., (2011), Willem } \\
\text { and Buelens (2007), and Yao et } \\
\text { al., (2007) }\end{array}$ \\
\hline $\begin{array}{l}\text { - Quite a few empirical studies include knowledge transfer in } \\
\text { private companies. ID fraudsters are too fast and smart to } \\
\text { adopt new methods of stealing personal information. } \\
\text { - An investigation of how individuals share their knowledge of } \\
\text { ID theft prevention in OROs in the UK is required. }\end{array}$ & $\begin{array}{l}\text { Bush (2016), Lai et al., (2016), } \\
\text { Madiwalar (2016), Yildirim } \\
\text { (2016), and Chohan et al., (2014) }\end{array}$ \\
\hline - $\quad$ Effective KS can be a significant production driver in OROs. & $\begin{array}{l}\text { Silvi and Cuganesan (2006), and } \\
\text { Gray and Laidlaw (2002) }\end{array}$ \\
\hline $\begin{array}{l}\text { Individuals are required to enhance their knowledge of ID } \\
\text { theft issues and how to secure information from fraudsters. }\end{array}$ & Yildirim (2016) \\
\hline
\end{tabular}




\section{Table 2. Research Instrument of the Study}

\begin{tabular}{|c|c|}
\hline Questions Asked & Sample Probe/ Further Questions \\
\hline \multicolumn{2}{|l|}{ Block 01: About Interviewee } \\
\hline $\begin{array}{l}\text { What are your work responsibilities related to information } \\
\text { security in the organisation? }\end{array}$ & Job title \\
\hline $\begin{array}{l}\text { How long have you been working in the organisation in that } \\
\text { position? }\end{array}$ & In what departments and groups? \\
\hline \multicolumn{2}{|l|}{ Block 02: KM Infrastructure } \\
\hline $\begin{array}{l}\text { What are the tools being used for sharing the knowledge for ID } \\
\text { theft prevention in the organisation? }\end{array}$ & $\begin{array}{l}\text { What are IT skills you required to have } \\
\text { for sharing the knowledge for ID theft } \\
\text { prevention? }\end{array}$ \\
\hline $\begin{array}{l}\text { How satisfied are you with the availability of the existing } \\
\text { resources in your organisation for sharing the knowledge for ID } \\
\text { theft prevention? }\end{array}$ & If not, then why? \\
\hline $\begin{array}{l}\text { To what extent you are satisfied with the usage of the existing } \\
\text { resources provided in your organisation for the knowledge sharing } \\
\text { for ID theft prevention? }\end{array}$ & If not, then what are the reasons? \\
\hline \multicolumn{2}{|l|}{ What other resources would you like to have available to you? } \\
\hline \multicolumn{2}{|l|}{ Block 03: ICT Know-how and Training } \\
\hline $\begin{array}{l}\text { How do you provide training to workers for enhancing their } \\
\text { knowledge sharing skills for ID theft prevention in your } \\
\text { organisation? (for managers only) }\end{array}$ & $\begin{array}{l}\text { How do you get training to enhance } \\
\text { your skills for knowledge sharing for ID } \\
\text { theft prevention in your organisation? } \\
\text { (for employees) }\end{array}$ \\
\hline $\begin{array}{l}\text { What advantages do you get from the training given for } \\
\text { knowledge sharing for ID theft prevention in your organisation? }\end{array}$ & $\begin{array}{l}\text { How do you implement the knowledge } \\
\text { given in training for knowledge sharing } \\
\text { for ID theft prevention? }\end{array}$ \\
\hline $\begin{array}{l}\text { Are these learning opportunities useful to you for sharing } \\
\text { knowledge for ID theft prevention? }\end{array}$ & If yes, then how? \\
\hline Block 04: Job Rotation & \\
\hline $\begin{array}{l}\text { Does your organisation practice job rotation to increase the } \\
\text { knowledge of the employees? }\end{array}$ & If no, then why? \\
\hline $\begin{array}{l}\text { How useful is job rotation for increasing the knowledge of the } \\
\text { employees for the prevention of ID theft in your organisation? }\end{array}$ & $\begin{array}{l}\text { How do individuals gain an advantage } \\
\text { of knowledge sharing for ID theft } \\
\text { prevention from job rotation? } \\
\text { How do teams get the benefit from job } \\
\text { rotation for the knowledge sharing for } \\
\text { ID theft prevention? }\end{array}$ \\
\hline Block 05: Feedback on Performance Evaluation & 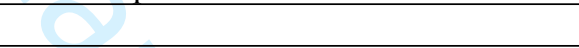 \\
\hline $\begin{array}{l}\text { How does your organisation evaluate the performance of } \\
\text { employees for the knowledge sharing for ID theft prevention? }\end{array}$ & If not, then why? \\
\hline \multicolumn{2}{|l|}{$\begin{array}{l}\text { How does feedback on the performance of employees' impact on } \\
\text { the knowledge sharing for ID theft prevention in your } \\
\text { organisation? }\end{array}$} \\
\hline Block 06: Information Sourcing Opportunities & \\
\hline $\begin{array}{l}\text { Which information sources are provided to you for sharing the } \\
\text { knowledge for ID theft prevention? (Email, internal network } \\
\text { messaging, policy documents, text messages on cell phones). }\end{array}$ & $\begin{array}{l}\text { Which of these resources do you prefer } \\
\text { to use? Why? } \\
\text { Which of these sources do you get the } \\
\text { most up-to-date information from? }\end{array}$ \\
\hline \multicolumn{2}{|l|}{$\begin{array}{l}\text { What other sources do you require for the knowledge sharing for } \\
\text { ID theft prevention in the organisation? }\end{array}$} \\
\hline Block 07: Leadership Support & 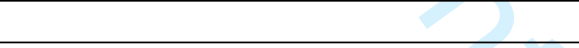 \\
\hline $\begin{array}{l}\text { How does management share the knowledge for ID theft } \\
\text { prevention with employees in the organisation? (for managers } \\
\text { only) }\end{array}$ & $\begin{array}{l}\text { In what way do you receive information } \\
\text { for ID theft prevention? (for employees) }\end{array}$ \\
\hline \multicolumn{2}{|l|}{$\begin{array}{l}\text { What support do you expect from top management of your } \\
\text { organisation for the knowledge sharing for ID theft prevention? }\end{array}$} \\
\hline & \\
\hline
\end{tabular}


Do you trust others concerning the knowledge sharing for ID theft prevention in your organisation?

If no, then why?

Do others, such as your colleagues in

Do you share knowledge concerning ID theft prevention with the same department or other your colleagues in the organisation? departments, share the knowledge for ID theft prevention with you?

What cultural changes (such as trust of other employees, communication with others and the behaviour of the information system) do you consider to be effective for the knowledge sharing for ID theft prevention in the organisation? 
Table 3. List of Interview Participants in $C X$

\begin{tabular}{|c|c|c|c|}
\hline $\begin{array}{l}\text { Participant } \\
\text { Code }\end{array}$ & $\begin{array}{l}\text { Participant } \\
\text { Department }\end{array}$ & Participant Job Responsibility & $\begin{array}{l}\text { Participant } \\
\text { Experience }\end{array}$ \\
\hline CX-R01 & Group Security & Performance management. & 9 years \\
\hline CX-R02 & $\begin{array}{l}\text { Fraud } \\
\text { Prevention }\end{array}$ & $\begin{array}{l}\text { To action referrals, speaking to genuine } \\
\text { customers who have been the victims of ID theft } \\
\text { and solving their issues for them. }\end{array}$ & 8 years \\
\hline CX-R03 & $\begin{array}{l}\text { Fraud } \\
\text { Prevention }\end{array}$ & $\begin{array}{l}\text { Looking at online applications for credit. Dealing } \\
\text { with victims of ID theft, attending to calls from } \\
\text { victims and explaining to them what to do and } \\
\text { helping them. }\end{array}$ & 10 years \\
\hline CX-R04 & Group Security & Internal consultancy. & 10 years \\
\hline CX-R05 & Group Security & Fraud and theft investigation and prevention. & 24 years \\
\hline CX-R06 & Group Security & $\begin{array}{l}\text { Threat detection, threat management and } \\
\text { vulnerability scanning. }\end{array}$ & 1 year \\
\hline CX-R07 & Group Security & $\begin{array}{l}\text { Group security, head of technical services and } \\
\text { training. }\end{array}$ & 14 years \\
\hline CX-R08 & Group security & $\begin{array}{l}\text { Information security specialist, making sure that } \\
\text { customer data is safe. Encryption of sensitive } \\
\text { information. }\end{array}$ & 10 years \\
\hline CX-R09 & Group Security & $\begin{array}{l}\text { Head of different departments. Consulting with } \\
\text { the managers of various departments, especially } \\
\text { group security, information security and fraud } \\
\text { prevention departments. }\end{array}$ & 10 years \\
\hline CX-R10 & $\begin{array}{l}\text { Fraud } \\
\text { Prevention }\end{array}$ & $\begin{array}{l}\text { Investigation of fraud and theft within the } \\
\text { business. }\end{array}$ & 17 years \\
\hline CX-R11 & $\begin{array}{l}\text { Intelligence } \\
\text { Unit }\end{array}$ & $\begin{array}{l}\text { Supporting the regional loss prevention managers } \\
\text { in their role and providing the information they } \\
\text { require. }\end{array}$ & 9 years \\
\hline CX-R12 & Group Security & $\begin{array}{l}\text { Analysis of data and putting packages together } \\
\text { and sending them out to the regional director. }\end{array}$ & 6 years \\
\hline CX-R13 & Group Security & Intelligence and technical lead. & 9 years \\
\hline CX-R14 & $\begin{array}{l}\text { Physical } \\
\text { Security }\end{array}$ & $\begin{array}{l}\text { Investigation of ID theft in terms of hijacked } \\
\text { accounts, fraudulent set up of accounts and } \\
\text { investigation of the web during the process of the } \\
\text { fraud being committed. }\end{array}$ & 6 years \\
\hline
\end{tabular}


Table 4. List of Interview Participants in $C Y$

\begin{tabular}{|c|c|c|c|}
\hline $\begin{array}{l}\text { Participant } \\
\text { Code }\end{array}$ & $\begin{array}{l}\text { Participant } \\
\text { Department }\end{array}$ & Participant Job Responsibility & $\begin{array}{l}\text { Participant } \\
\text { Experience }\end{array}$ \\
\hline CY-R01 & $\begin{array}{l}\text { Group } \\
\text { Business } \\
\text { Services }\end{array}$ & $\begin{array}{l}\text { Looking after the Microsoft estate including } \\
\text { cloud infrastructure. Making sure that } \\
\text { anything entered conforms to the correct } \\
\text { standards. }\end{array}$ & 15 Years \\
\hline CY-R02 & $\begin{array}{l}\text { Asset } \\
\text { Management }\end{array}$ & $\begin{array}{l}\text { Supporting the IBM infrastructure, IBM } \\
\text { officer application service infrastructure and } \\
\text { IBM WebSphere Messaging infrastructure. }\end{array}$ & 1 Year \\
\hline CY-R03 & $\begin{array}{l}\text { Information } \\
\text { Management } \\
\text { Department }\end{array}$ & $\begin{array}{l}\text { Responsible for managing data migration, } \\
\text { data security, hardware and software setup. }\end{array}$ & 5 Years \\
\hline CY-R04 & IT Department & Accountable for managing technical teams. & 2 Years \\
\hline CY-R05 & $\begin{array}{l}\text { Project and } \\
\text { Programme } \\
\text { Services }\end{array}$ & $\begin{array}{l}\text { A trainer, e-Learning, research and } \\
\text { development. Helping people's needs with } \\
\text { the right frameworks and right regulations. }\end{array}$ & 16 Years \\
\hline CY-R06 & Supply Chain & $\begin{array}{l}\text { Manage delivery of work stream. Working on } \\
\text { a desktop transformation programme. }\end{array}$ & 2 Months \\
\hline CY-R07 & PMPS & $\begin{array}{l}\text { Managing communication in the company. } \\
\text { Sending out communication emails to } \\
\text { individuals and teams. }\end{array}$ & 1 Year \\
\hline CY-R08 & $\begin{array}{l}\text { Desktop } \\
\text { Transformation } \\
\text { Program }\end{array}$ & $\begin{array}{l}\text { Supporting the regional loss prevention } \\
\text { managers in their role and providing the } \\
\text { information they require. }\end{array}$ & 1 Year \\
\hline CY-R09 & Supply Chain & $\begin{array}{l}\text { The commercialisation of excess capacity } \\
\text { from the supply chain including selling of } \\
\text { goods and services to third parties. }\end{array}$ & 2 Years \\
\hline CY-R10 & Supply Chain & $\begin{array}{l}\text { The commercialisation of excess capacity } \\
\text { from the supply chain including selling of } \\
\text { goods and services to third parties. }\end{array}$ & 1 Year \\
\hline CY-R11 & $\begin{array}{l}\text { Corporate } \\
\text { Functions }\end{array}$ & $\begin{array}{l}\text { To deliver business changes and new } \\
\text { technology, to time, to cost and to quality. }\end{array}$ & 5 Years \\
\hline CY-R12 & $\begin{array}{l}\text { Maintenance } \\
\text { and } \\
\text { Development }\end{array}$ & $\begin{array}{l}\text { Maintaining the ICT-infrastructure of the } \\
\text { company. }\end{array}$ & 3 Years \\
\hline CY-R13 & $\begin{array}{l}\text { Information } \\
\text { Security }\end{array}$ & $\begin{array}{l}\text { Responsible for securing information. } \\
\text { Looking after information security issues. }\end{array}$ & 2 Years \\
\hline
\end{tabular}


Table 5. List of Interview Participants in $C Z$

\begin{tabular}{|c|c|c|c|}
\hline $\begin{array}{l}\text { Participant } \\
\text { Code }\end{array}$ & $\begin{array}{l}\text { Participant } \\
\text { Department }\end{array}$ & Participant Job Responsibility & $\begin{array}{l}\text { Participant } \\
\text { Experience }\end{array}$ \\
\hline CZ-R01 & $\begin{array}{l}\text { Information } \\
\text { Technology }\end{array}$ & $\begin{array}{l}\text { Managing the website of the company, updating } \\
\text { web contents and handling the database at backend. }\end{array}$ & 7 Years \\
\hline CZ-R02 & $\begin{array}{l}\text { Information } \\
\text { Technology }\end{array}$ & $\begin{array}{l}\text { Looking after IT infrastructure, administrating } \\
\text { existing system including the network and hardware } \\
\text { in the company. }\end{array}$ & 5 Years \\
\hline CZ-R03 & $\begin{array}{l}\text { Information } \\
\text { security }\end{array}$ & $\begin{array}{l}\text { Handling information on security issues of the } \\
\text { company. Managing firewalls and secure lines for } \\
\text { the company. }\end{array}$ & 5 Years \\
\hline CZ-R04 & Call Centre & $\begin{array}{l}\text { Contacting the customers and providing sales } \\
\text { advice. }\end{array}$ & 3 Years \\
\hline CZ-R05 & Call Centre & $\begin{array}{l}\text { Contacting the customers and providing sales } \\
\text { advice. }\end{array}$ & 1 Year \\
\hline CZ-R06 & $\begin{array}{l}\text { Human } \\
\text { Resources }\end{array}$ & Managing human resources in the company. & 7 Years \\
\hline CZ-R07 & Call Centre & $\begin{array}{l}\text { Contacting the customers and providing sales } \\
\text { advice. }\end{array}$ & 3 Years \\
\hline
\end{tabular}


Table 6. A comparison of related frameworks

\begin{tabular}{|c|c|c|c|c|c|c|c|}
\hline \multirow[b]{2}{*}{ 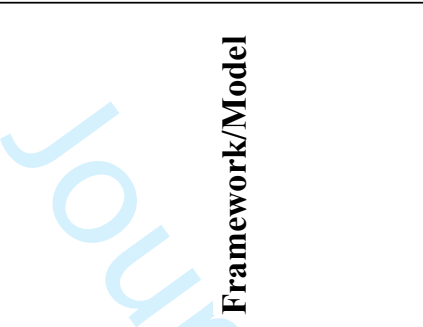 } & \multirow[b]{2}{*}{ 导 } & \multirow{2}{*}{ 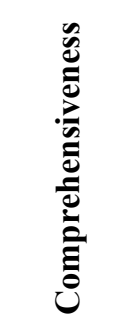 } & \multirow[b]{2}{*}{ 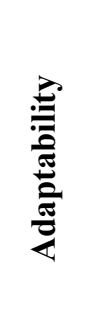 } & \multirow{2}{*}{ 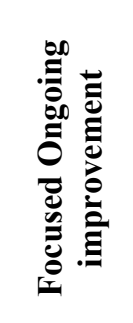 } & \multirow[b]{2}{*}{ 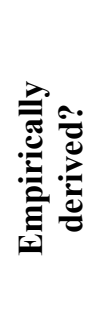 } & \multicolumn{2}{|c|}{$\begin{array}{c}\text { Focused } \\
\text { components }\end{array}$} \\
\hline & & & & & & 总 & 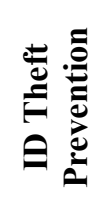 \\
\hline $\begin{array}{l}\text { Arachchilage and Love et al. } \\
\text { (2012) }\end{array}$ & No & No & $\mathrm{N} / \mathrm{A}$ & No & Yes & Yes & Yes \\
\hline Trkman and Desouza (2012) & No & Limited & $\mathrm{N} / \mathrm{A}$ & No & Yes & Yes & No \\
\hline Yan Li and Zetian Fu (2007) & No & Limited & $\mathrm{N} / \mathrm{A}$ & N/A & Yes & Yes & No \\
\hline Amin et al. (2010) & N/A & Limited & No & Limited & Yes & Yes & No \\
\hline WenJie Wang et al. (2006) & N/A & N/A & $\mathrm{N} / \mathrm{A}$ & No & No & No & Yes \\
\hline Noor and Salim (2012) & Yes & Limited & No & Limited & Yes & Yes & No \\
\hline Salleh (2010) & Yes & Yes & Yes & Yes & Yes & Yes & No \\
\hline
\end{tabular}




\begin{tabular}{|c|c|c|c|c|c|}
\hline \multirow{2}{*}{$\begin{array}{l}\text { KS Enablers } \\
\text { for ID Theft } \\
\text { Prevention } \\
\text { KS Process }\end{array}$} & \multirow{2}{*}{ 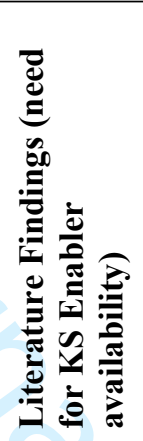 } & \multicolumn{3}{|c|}{$\begin{array}{l}\text { Use of KS Enablers } \\
\text { for ID Theft } \\
\text { Prevention } \\
\text { Knowledge Process }\end{array}$} & \multirow{2}{*}{ Recommendations of This Study } \\
\hline & & 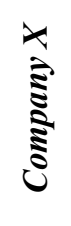 & 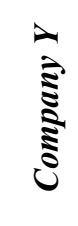 & 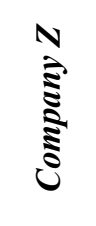 & \\
\hline $\begin{array}{l}\text { KM } \\
\text { Infrastructure }\end{array}$ & Yes & No & No & No & $\begin{array}{l}\text { The organisations should design and implement an } \\
\text { effective KM infrastructure for learning how to } \\
\text { share the knowledge of ID theft prevention. }\end{array}$ \\
\hline $\begin{array}{l}\text { ICT Know- } \\
\text { How and } \\
\text { Training }\end{array}$ & Yes & No & No & No & $\begin{array}{l}\text { The organisations should design a comprehensive } \\
\text { ICT know-how and training programme to educate } \\
\text { the staff to share ID theft prevention knowledge. }\end{array}$ \\
\hline Job Rotation & Yes & No & No & No & $\begin{array}{l}\text { The organisations need to enable a job rotation } \\
\text { process to facilitate a learning process for } \\
\text { individuals who need to enhance their knowledge } \\
\text { of ID theft prevention within and outside their } \\
\text { working departments in the organisations. }\end{array}$ \\
\hline $\begin{array}{l}\text { Feedback on } \\
\text { Performance } \\
\text { Evaluation }\end{array}$ & Yes & No & No & No & $\begin{array}{l}\text { The organisations need to implement an employee } \\
\text { evaluation process and provide feedback regarding } \\
\text { ID theft prevention KS and how to improve the } \\
\text { knowledge of ID theft prevention. }\end{array}$ \\
\hline $\begin{array}{l}\text { Information } \\
\text { Sourcing } \\
\text { Opportunities }\end{array}$ & Yes & No & No & No & $\begin{array}{l}\text { The OROs need to utilise and increase information } \\
\text { sourcing opportunities for better learning of } \\
\text { individual staff members for ID theft prevention } \\
\text { KS. }\end{array}$ \\
\hline
\end{tabular}

Support of leadership is required for individual staff members to learn to share knowledge of ID theft prevention in the organisations. Leadership should take steps for the development $\begin{array}{llll}\text { Leadership } & \text { Yes } & \text { No } & \text { No }\end{array}$ of a policy for individual staff learning to share the knowledge of ID theft prevention. Employee training and other learning activities are required in the online retail sector for the awareness of individual staff members to share the knowledge of ID theft prevention.

The organisations should develop an employee learning culture of KS to prevent ID theft at intra-

Knowledge

Sharing

Culture Yes organisation level.

The trust of other staff members working in nontechnical departments should be increased for ID theft prevention KS in the organisations so that individuals working in the companies share knowledge with confidence and boost the awareness of individual knowledge to prevent ID theft. 
Figure 2. Knowledge sharing processes for ID theft prevention within organisations (extended framework proposed by Chong et al., (2011)) 


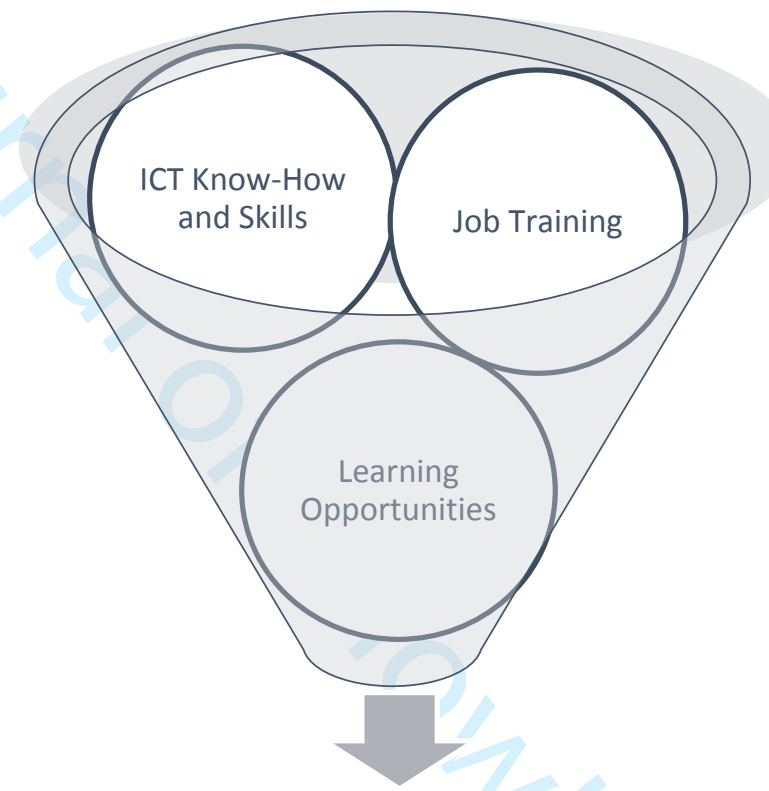

ICT Know-How and Training

Figure 3. ICT Know-How and Training - an extended factor 
Figure 4. KM Infrastructure - an extended factor 
Response to Reviewers Document for: Manuscript ID JKM-06-2018-0370.R1 entitled "An investigation into agile learning processes and knowledge sharing practices to prevent identity theft in online retail organisations"

Comment Authors Response

Overall comment to the Guest Editor

The paper has now been revised in line with the outstanding reviewer issues. The paper has been formatted in line with the formatting requirements for the journal. The correct format has been applied to the abstract and final reference list.

\section{Reviewer 1 Accept}

1.1 Reviewer 1 decision is accept

1.1R. We thank the reviewer for their time and kind comments regarding the manuscript.

\section{Reviewer 2 Minor Revision}

2.1 Focus on Discussion section where you showcase the results of the research objectives. This will strengthen your manuscript immensely. Be careful, you already have 6 pages of References in your manuscript.

2.1R. We have further edited and revised the discussion section in line with your comments. We believe the Discussion is now more focused and relevant. In addition, we have edited the references to reduce the occurrences of multiple references in the body of the text.

\section{Additional Questions}

2.2. Originality:

Does the paper contain new and significant information adequate to justify publication?: Yes.

\subsection{Relationship to Literature:}

Does the paper demonstrate an adequate understanding of the relevant literature in the field and cite an appropriate range of literature sources? Is any significant work ignored?: It is satisfactory.

\subsection{Methodology:}

Is the paper's argument built on an appropriate base of theory, concepts, or other ideas? Has the research or equivalent intellectual work on which the paper is based been well designed? Are the methods employed appropriate?: What is the reliability and validity of your results? You should focus on triangulation technique to ensure reliability and validity of your results. Explain how you have undertaken it. Yes

\subsection{Results:}

Are results presented clearly and analysed appropriately? Do the conclusions adequately tie together the other elements of the paper?: It is appropriate.
2.2R. We thank the reviewer for their comments here.

\subsection{R We thank the reviewer for their} comments here.

2.4R We thank the reviewer for their comments here.

$2.5 \mathrm{R}$ We thank the reviewer for their comments here. 


\begin{tabular}{|l|l|}
\hline $\begin{array}{l}\text { 2.6. Implications for research, practice } \\
\text { and/or society: }\end{array}$ & $\begin{array}{l}\text { 2.6R The Discussion section has been } \\
\text { heavily edited to improve its readability, } \\
\text { flow and impact. The bullet points have } \\
\text { Does the paper identify clearly any } \\
\text { implications for research, practice and/or } \\
\text { society? Does the paper bridge the gap } \\
\text { now more concise and relevant to the focus } \\
\text { of the study. }\end{array}$ \\
$\begin{array}{l}\text { research be used in practice (economic and } \\
\text { commercial impact), in teaching, to } \\
\text { influence public policy, in research } \\
\text { (contributing to the body of }\end{array}$ & \\
$\begin{array}{l}\text { knowledge)? What is the impact upon } \\
\text { society (influencing public attitudes, } \\
\text { affecting quality of life)? Are these } \\
\text { implications consistent with the findings } \\
\text { and conclusions of the paper?: The }\end{array}$ & \\
$\begin{array}{l}\text { Discussion is still weak and the author(s) } \\
\text { should further strengthen it instead of } \\
\text { writing mere bullet points. }\end{array}$ & \\
\hline $\begin{array}{l}\text { 2.7. Quality of Communication: } \\
\text { Does the paper clearly express its case, } \\
\text { measured against the technical language of } \\
\text { the field and the expected knowledge of the } \\
\text { journal's readership? Has attention been } \\
\text { paid to the clarity of expression and } \\
\text { readability, such as sentence structure, } \\
\text { jargon use, acronyms, etc.: There are still } \\
\text { grammatical errors in the manuscript and } \\
\text { please proof-read it again before you submit } \\
\text { the revised manuscript. }\end{array}$ & $\begin{array}{l} \\
\text { and proof-read the document to improve its } \\
\text { grammatical errors. }\end{array}$ \\
\end{tabular}

